\title{
INFLUENCE OF THE HYPOPHYSIS ON PREGNANT MARE'S SERUM GONADOTROPHIN-INDUCED OVULATION IN IMMATURE RATS
}

\author{
M. DE LA LASTRA, M. L. FORGELLEDO AND C. SERRANO \\ Laboratorio de Endocrinología, Instituto de Ciencias Biológicas, \\ Universidad Católica de Chile, Casilla 114-D, Santiago-Chile
}

(Received 10th August 1971, accepted 4th September 1971)

\begin{abstract}
Summary. The injection of 30 i.u. PMSG in 27 -day-old rats produced an ovulatory response which began after 24 to $36 \mathrm{hr}$ and reached a maximum $72 \mathrm{hr}$ after gonadotrophin treatment. There were two increments in the number of ova within this period: between 36 and $48 \mathrm{hr}$ and between 60 and $72 \mathrm{hr}$. The results of timed experiments involving chlorpromazine blockade or hypophysectomy suggest that the first increment in the number of ova is independent of the pituitary gland but influenced by it. The latter increase seems to be pituitary-dependent since both procedures suppressed it.
\end{abstract}

\section{INTRODUCTION}

Superovulation in the immature rat can be induced by a single injection of PMSG. This effect seems to be due both to a certain intrinsic luteinizing property of PMSG and to its ability to cause release of endogenous ovulating hormone (Williams, 1945a, b).

Strauss \& Meyer (1962) have given evidence that ovulation in 32-day-old rats treated with 8 i.u. PMSG depends upon the release of pituitary ovulating hormone during a critical period between 14.00 and 16.00 hours of the 2nd day after PMSG injection. The number of animals which ovulated following hypophysectomy which had been performed at various times before ovulation indicated that the pituitary was essential only until the late afternoon before ovulation. This was confirmed by Quinn \& Zarrow (1964) in 24-day-old rats treated with 30 i.u. PMSG (Equinex). Hypophysectomy performed 24, 48 and $52 \mathrm{hr}$ after PMSG completely suppressed ovulation. After $56 \mathrm{hr}$, ovulation occurred in $38.5 \%$, and after $60 \mathrm{hr}$, in $87.5 \%$, of the rats. These authors concluded that the length of time required for 30 i.u. PMSG to bring about the release of LH in the 24-day-old immature rat was approximately $56 \mathrm{hr}$ as determined by hypophysectomy, and between 56 and $60 \mathrm{hr}$ as determined by blockade with drugs.

We have produced superovulation in 27-day-old immature rats injected with 30 i.u. PMSG. This treatment is effective in almost $100 \%$ of the rats. Most of the ova recovered from the oviducts 72 to 76 hours after PMSG injection were in cumulus. However, some of them were denuded, and even fragmented, 
suggesting that the ova had been released from the ovaries at different times, rather than in a single discharge as is generally supposed to occur. As a consequence of these observations, we decided to study in greater detail the process of superovulation in Sprague-Dawley rats injected with 30 i.u. PMSG under the conditions standardized in our laboratory.

\section{MATERIALS AND METHODS}

Sprague-Dawley rats bred in our laboratory were kept under controlled lighting conditions in which the light was turned on from 07.00 to 21.00 hours. Unrestricted supplies of pelleted rat food and water were available.

When the rats were 27 days old, they were injected subcutaneously between 09.00 and 10.00 hours (zero hour of the experiments) with 10 or 30 i.u. PMSG (Equinex, Ayerst Laboratories) dissolved in $0.2 \mathrm{ml}$ of $0.9 \% \mathrm{NaCl}$ solution.

The rats were killed with ether after $24,36,48,60$ or $72 \mathrm{hr}$. Ovaries and uteri were removed and weighed on a torsion balance to the nearest $0.2 \mathrm{mg}$. Before being weighed, the ovaries were dissected free of adipose tissue and the uteri were freed of mesometrium and luminal fluid. The Fallopian tubes were examined for the presence and number of ova according to the techniques of Rowlands (1942) and Zarrow, Caldwell, Hafez \& Pincus (1958).

\section{Chlorpromazine $(C P)$ blocking experiments}

A group of rats was injected subcutaneously with CP (Largactil, Laboratorio Colliere) at a dosage of $1 \mathrm{mg} / 100 \mathrm{~g}$ body weight 24 to $28 \mathrm{hr}$ or 48 to $53 \mathrm{hr}$ after the administration of 30 i.u. PMSG. Autopsies were performed 48 or $72 \mathrm{hr}$ after the PMSG had been injected.

\section{Hypophysectomy}

Rats injected with 30 i.u. PMSG were hypophysectomized by the transauricular method of Koyama (1962) between 24 and $30 \mathrm{hr}$, and autopsy was performed $48 \mathrm{hr}$, after the time of the PMSG injection. Other rats receiving the same treatment were hypophysectomized at $48 \mathrm{hr}$, and subjected to autopsy $72 \mathrm{hr}$ after PMSG injection.

Another group was hypophysectomized 1 to $24 \mathrm{hr}$ before the injection of 30 i.u. PMSG and autopsy was performed 48 or $72 \mathrm{hr}$ after gonadotrophin treatment. The completeness of hypophysectomy was checked by direct inspection of the sella turcica region and all rats having pituitary fragments were excluded. Rats subjected to sham hypophysectomy served as controls.

After the surgical procedures, the animals were injected with a single dose of $80 \mu \mathrm{g}$ 9- $\alpha$-fluoro-16- $\beta$ methylprednisolone (Cidoten, Schering Corporation), and their drinking water was replaced by a solution of $5 \%$ glucose.

\section{RESULTS}

The number of ova found at various times after the injection of 30 i.u. PMSG is shown in Text-fig. 1. Some ovulations occurred as early as $24 \mathrm{hr}$ after PMSG. By $36 \mathrm{hr}$, ovulation had occurred in $81 \%$ of the rats with an average of $3.9 \pm 0.9$ 
ova/rat. The number of ova increased thereafter, reaching a plateau at $48 \mathrm{hr}$ which was maintained throughout the next $12 \mathrm{hr}$. However, at $72 \mathrm{hr}$, the number of ova had increased significantly over the number found at 48 to $60 \mathrm{hr}$.

The ovulatory response $48 \mathrm{hr}$ after the injection of $10 \mathrm{i}$.u. PMSG was insignificant, but at $72 \mathrm{hr}$, as related to zero time, $88 \%$ of the rats had ovulated, a mean of $18 \cdot 8 \pm 2 \cdot 3 \mathrm{ova} / \mathrm{rat}$ (Table 3 ).

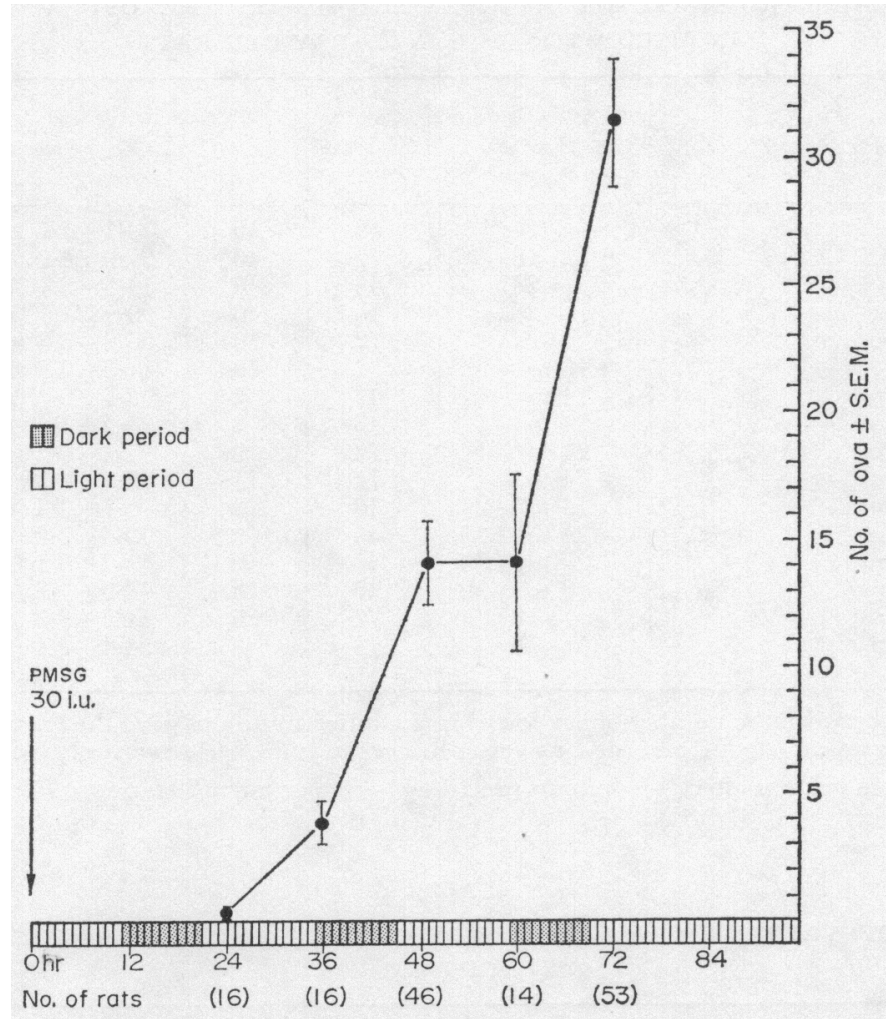

TEXT-FIG. 1. Time course of the increase in the number of ova collected from the oviducts of 27-day-old rats at different periods after the injection of 30 i.u. PMSG. The abscissa shows intervals of $1 \mathrm{hr}$ and periods of light and darkness. The upper line of numbers under the abscissa represents hours after PMSG injection, which was performed at $0 \mathrm{hr}(10.00$ hours).

The effects of GP and hypophysectomy are shown in Table 1. Both procedures, when performed between 24 and $30 \mathrm{hr}$, failed to reduce the ovulatory response at $48 \mathrm{hr}$. When these procedures were performed at $48 \mathrm{hr}$, the second increase in the number of ova, which is observed in normal rats at $72 \mathrm{hr}$, was suppressed. Chlorpromazine injected at $24 \mathrm{hr}$ did not change the normal ovulatory response observed at $72 \mathrm{hr}$.

When 30 i.u. PMSG were injected in rats hypophysectomized 1 to $24 \mathrm{hr}$ previously, the number of ova found at 48 and $72 \mathrm{hr}$ as related to PMSG injection was significantly smaller than the control values (Table 1).

The effects of different doses of PMSG upon ovulation at 48 and $72 \mathrm{hr}$ are shown in Table 2. 


\section{DISCUSSION}

The rats used in these experiments ovulated as early as $24 \mathrm{hr}$ after the injection of 30 i.u. PMSG. This result is not in accordance with the reports of other investigators (Strauss \& Meyer, 1962; Quinn \& Zarrow, 1964), who have given

\section{TABLE 1}

EFFECT OF CHLORPROMAZINE OR HYPOPHYSEGTOMY ON THE OVULATORY RESPONSE INDUGED WITH PMSG IN 27-DAY-OLD RATS

\begin{tabular}{|c|c|c|c|c|c|}
\hline Treatment & $\begin{array}{l}\text { Time of } \\
\text { treatment* }\end{array}$ & $\begin{array}{l}\text { Time* of } \\
\text { autopsy }\end{array}$ & $\begin{array}{l}\text { No. of } \\
\text { rats }\end{array}$ & $\begin{array}{c}\text { No. of ova/rat } \\
(\text { mean } \pm \text { S.E.M. })\end{array}$ & $\begin{array}{l}\% \text { rats } \\
\text { ovulating }\end{array}$ \\
\hline $\begin{array}{l}\text { Saline } \\
\text { Saline } \\
\text { Chlorpromazine } \\
1 \mathrm{mg} \times 100 \mathrm{~g} \text { body wt } \\
\text { Hypophysectomy } \\
\text { Sham operation } \\
\text { Hypophysectomy } \\
\text { Sham operation } \\
\text { Hypophysectomy } \\
\text { Sham operation } \\
\text { Hypophysectomy } \\
\text { Sham operation } \\
\text { Hypophysectomy } \\
\text { Sham operation }\end{array}$ & $\begin{array}{c}+24 \\
+48 \\
+24 \\
+28 \\
+24 \\
+48 \text { to }+53 \\
-24 \text { to }-1 \\
-24 \text { to }-1 \\
-24 \text { to }-1 \\
-24 \text { to }-1 \\
+24 \text { to }+25 \\
+24 \text { to }+25 \\
+28 \text { to }+30 \\
+28 \text { to }+30 \\
+48 \\
+48\end{array}$ & $\begin{array}{l}48 \\
72 \\
48 \\
48 \\
72 \\
72 \\
48 \\
48 \\
72 \\
72 \\
48 \\
48 \\
48 \\
48 \\
72 \\
72\end{array}$ & $\begin{array}{r}46 \\
40 \\
6 \\
6 \\
10 \\
40 \\
6 \\
8 \\
9 \\
11 \\
13 \\
8 \\
10 \\
13 \\
9 \\
8\end{array}$ & 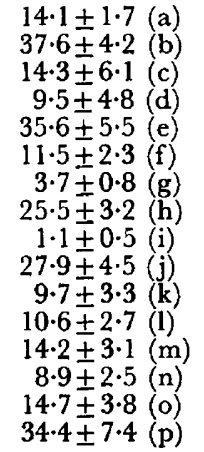 & $\begin{array}{r}93 \\
95 \\
100 \\
83 \\
100 \\
80 \\
100 \\
100 \\
55 \\
90 \\
85 \\
87 \\
90 \\
100 \\
100 \\
100\end{array}$ \\
\hline
\end{tabular}

Comparison between the number of ova found in the different groups gave the following values of $P$ in the Student's test: $P<0.001$, a versus $\mathrm{b} ; \mathrm{g}$ versus $\mathrm{h} ; \mathrm{i}$ versus $\mathrm{j} ; P<0.01$, e versus $\mathrm{f} ; P<0.05$, 0 versus $\mathrm{p}$.

* Time is given in hours after $(+)$ or hours preceding $(-)$ injection of 30 i.u. PMsG (Groups g, h, i,j).

TABLE 2

OVULATORY RESPONSE OF 27-DAY-OLD RATS TO DIFFERENT DOSES OF PMSG

\begin{tabular}{c|c|c|c|c}
\hline $\begin{array}{c}P M S G \\
(\text { i.u. })\end{array}$ & $\begin{array}{c}\text { Autopsy } \\
(\text { hr after PMSG) }\end{array}$ & $\begin{array}{c}\text { No. of } \\
\text { rats }\end{array}$ & $\begin{array}{c}\text { No. of ova/rat } \\
\text { (mean } \pm \text { S.E.M. })\end{array}$ & $\%$ \% rats ovulating \\
\hline 5 & 72 & 9 & $8 \cdot 2 \pm 0 \cdot 2$ & 100 \\
10 & 72 & 17 & $18 \cdot 8 \pm 2 \cdot 3$ & 88 \\
30 & 72 & 53 & $31 \cdot 4 \pm 2 \cdot 6$ & 100 \\
10 & 48 & 11 & $0 \cdot 5 \pm 0 \cdot 2$ & 27 \\
30 & 48 & 46 & $14 \cdot 1 \pm 1 \cdot 7$ & 93 \\
\hline
\end{tabular}

The responses to each dose of PMSG differ significantly in both periods of observations ( $P$ values in Student's test $<0.001$ ).

evidence that, for ovulation to occur in immature rats following PMSG injection, the release of endogenous LH must take place approximately $56 \mathrm{hr}$ later. This difference may be due to the age of the rats at the time of the gonadotrophin injection, since most of the earlier reports deal with 20- to 24-day-old rats, whereas ours were 27 days old. At this latter age, the rat shows the maximum ovulatory response to PMSG (Zarrow \& Quinn, 1963). 
Zarrow \& Gallo (1969) mentioned the occurrence of ovulation $48 \mathrm{hr}$ after the injection of 30 i.u. PMSG in 30-day-old rats. The response, however, was smaller than that reported here. In two of their experiments, only $9 \%$ and $12 \%$ of the rats had ovulated at that time and the mean number of ova/rat was $1.5 \pm 1.4$ and $1.8 \pm 1 \cdot 8$, respectively.

The different strain of the rats may be another source of variation since our rats were Sprague-Dawley and most of the other reports refer to PurdueWistar or Holtzman strains. According to Zarrow \& Quinn (1963), the last two strains give different responses at $48 \mathrm{hr}$ to the same dose of PMSG.

In our experiments, the number of ova recovered from the oviducts increased after the second and third periods of darkness following PMSG treatment. The first increase was not modified by chlorpromazine treatment or by hypophysectomy performed between 24 and $28 \mathrm{hr}$ after PMSG, whereas both procedures performed at $48 \mathrm{hr}$ suppressed the second increase, normally observed at $72 \mathrm{hr}$.

\section{TABLE 3}

INFLUENGE OF THE PITUITARY ON THE OVARIAN, UTERINE AND OVULATORY RESPONSE OBTAINED IN 27-DAY-OLD RATS 48 HR AFTER THE INJEGTION OF PMSG

\begin{tabular}{|c|c|c|c|c|c|c|}
\hline $\begin{array}{c}\text { Time of } \\
\text { hypophysectomy }\end{array}$ & $\begin{array}{c}\text { No. of } \\
\text { rats }\end{array}$ & $\begin{array}{c}\text { Body weight } \\
(g \pm S . E . M .)\end{array}$ & $\begin{array}{c}\text { Weight of } \\
\text { ovaries } \\
\text { (mg } \pm \text { S.E.M.) }\end{array}$ & $\begin{array}{c}\text { Weight of } \\
\text { uterus } \\
(m g \pm S . E . M .)\end{array}$ & $\begin{array}{c}\text { No. of } \\
\text { ovalrat } \\
\text { (Mean } \pm \text { S.E.M. })\end{array}$ & $\begin{array}{c}\% \text { rats } \\
\text { ovulating }\end{array}$ \\
\hline $\begin{array}{l}-24 \text { to }-1 \\
+28 \text { to }+30\end{array}$ & $\begin{array}{r}6 \\
10\end{array}$ & $\begin{array}{l}57 \cdot 0 \pm 6 \cdot 8 \\
59 \cdot 0 \pm 3 \cdot 2\end{array}$ & $\begin{array}{c}36 \cdot 03 \pm 4 \cdot 9 \\
60 \cdot 1 \pm 2 \cdot 7^{* *}\end{array}$ & $\begin{array}{l}40 \cdot 1 \pm 3 \cdot 0 \\
62 \cdot 1 \pm 6 \cdot 1^{*}\end{array}$ & $\begin{array}{r}3 \cdot 7 \pm 0 \cdot 8 \\
14 \cdot 2 \pm 3 \cdot 1\end{array}$ & $\begin{array}{r}100 \\
90\end{array}$ \\
\hline
\end{tabular}

PMSG (30 i.u.) was injected at 10.00 hours. $-=$ hours before PMSG; $+=$ hours after PMSG.

* $P<0.01$; ** $P<0.001$.

These results suggest that the ovulatory response to PMSG has two different components: the first one occurs within the first $48 \mathrm{hr}$ and is independent of the pituitary gland, while the second occurs between 60 and $72 \mathrm{hr}$ and is pituitarydependent.

This finding does not indicate that the pituitary has no influence on the first stage of induced ovulation. The ovulatory response was actually greater in those rats with intact pituitaries during the first $24 \mathrm{hr}$ after PMSG injection than in those which had been previously hypophysectomized. In the former group, the weights of the uteri and ovaries were also greater, which suggests a response to some endogenous gonadotrophins or the participation of other hormones of the pituitary (Table 3 ).

Ovulation occurring in rats hypophysectomized before gonadotrophin injection must therefore be due to the action of PMSG alone, which is known to possess some weak luteinizing activity. This gonadotrophin has a half-life of $26 \mathrm{hr}$ (Parlow \& Ward, 1961). During the first part of this interval, it may stimulate the growth of the ovarian follicles, and the level remaining in the blood 24 to $30 \mathrm{hr}$ after the injection of a large dose may be sufficient to induce ovulation. The low ovulatory response evoked by $10 \mathrm{i}$.u. PMSG at $48 \mathrm{hr}$ as compared to 30 i.u. (Table 2) is consistent with this concept. With the smaller dose, 
the gonadotrophin level remaining after 24 to $30 \mathrm{hr}$ may be subovulatory, and ovulation will occur only after the secretion of LH. This may explain why hypophysectomy, performed $52 \mathrm{hr}$ after the injection of 8 i.u. PMSG in 32-day-old rats, suppressed the ovulatory response to this hormone (Strauss \& Meyer, 1962).

Rowlands \& Williams (1942) have reported the induction of ovulation in hypophysectomized rats by the injection of two doses of 40 i.u. PMSG given at an interval of 7 days, but not with a single dose. The explanation of this difference may be the fact that their experiments were performed with rats hypophysectomized 5 days previously, so that their ovaries had become atrophic when the gonadotrophin was injected. Since our rats were hypophysectomized shortly before PMSG injection, their ovaries probably contained normally developing follicles at the time when the gonadotrophin began to act.

\section{ACKNOWLEDGMENTS}

This research was supported by the Fondo de Investigaciones de la Universidad Católica de Chile. The authors are indebted to Miss Gladys Suárez for her able technical assistance.

\section{REFERENCES}

Koyama, R. (1962) A simple method of hypophysectomy in rats (Koyama's external auditory canal method). Endocr. jap. 9, 321.

PARLOw, A. F. \& WARD, D. N. (1961) Rate of disappearance of LH, PMS and HCG from plasma. In: Human Pituitary Gonadotropins, p. 204. Ed. A. Albert. Charles C. Thomas, Springfield, Illinois.

QUINN, D. L. \& ZARROW, M. X. (1964) Inhibition of pregnant mare's serum-induced ovulation in the immature rat. Endocrinology, 74, 309.

Rowlands, I. W. (1942) Collection of eggs from the Fallopian tube of the rat. Nature, Lond. 150, 267.

Rowlands, I. W. \& Williams, P. C. (1942) Production of ovulation in hypophysectomized rats. $\mathcal{F}$. Endocr. 3, 310.

Strauss, W. F. \& MEyer, R. K. (1962) Neural timing of ovulation in immature rats treated with gonadotrophin. Science, N.Y. 137, 860.

Williams, P. C. (1945a) Studies of the biological action of serum gonadotrophin. 1. Decline in ovarian response after hypophysectomy. F. Endocr. 4, 127.

Wirliams, P. C. (1945b) Studies of the biological action of serum gonadotrophin. 2. Ovarian response after hypophysectomy and oestrogen treatment. F. Endocr. 4, 131.

Zarrow, M. X., Caldwell, A. G., JR, Hafez, E. S. E. \& Pincus, G. (1958) Superovulation in the immature rat as a possible assay for $\mathrm{LH}$ and HCG. Endocrinology, 63, 748.

Zarrow, M. X. \& Gallo, R. V. (1969) Action of progesterone on PMs-induced ovulation in the immature rat. Endocrinology, 84, 1274.

ZARrow, M. X. \& Quin, D. L. (1963) Superovulation in the immature rat following treatment with PMS alone and inhibition of PMs-induced ovulation. F. Endocr. 26, 181. 